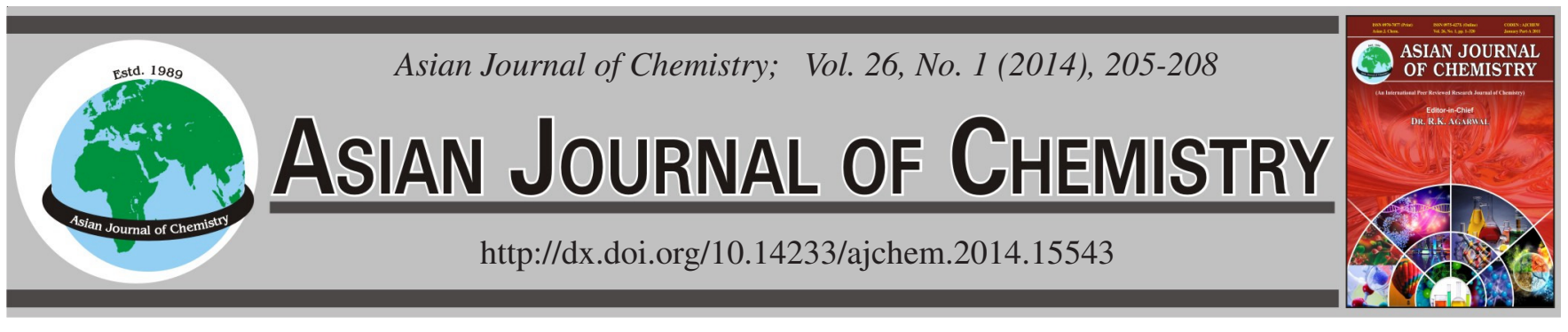

\title{
Enhancing Nitrogen Removal in Coking Wastewater Treatment by Activated Sludge Process: Comparison of Sodium Acetate, Methanol and Phenol as External Carbon Source for Denitrification
}

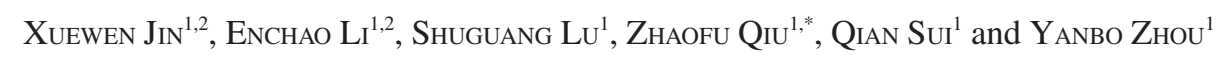

${ }^{1}$ State Environmental Protection Key Laboratory of Environmental Risk Assessment and Control on Chemical Process, East China University of Science and Technology, Shanghai 200237, P.R. China

${ }^{2}$ Shanghai Baosteel Chemical Co. Ltd., Shanghai 201901, P.R. China

*Corresponding author: Tel: +86 21 64250709; E-mail: zfqiu@ecust.edu.cn; xuminhui@outlook.com

\begin{abstract}
A lab-scale test for the treatment of coking wastewater mainly generated in coal carbonization and gas purification in Shanghai Baosteel Chemical Co. Ltd. was carried out by modification of its former anoxic-oxic (A/O) process into anoxic-oxic-anoxic-oxic (A/O/A/O). Three external carbon sources, namely sodium acetate, methanol and phenol, were investigated aiming for enhancement of denitrification purpose. The experimental results showed that total nitrogen could be lowered to 14.5 or $17.6 \mathrm{mg} / \mathrm{L}$ when adding sodium acetate (1875 $\mathrm{mg} / \mathrm{L})$ or methanol $(880 \mathrm{mg} / \mathrm{L})$ to the secondary modified anoxic zone and in both cases organic nitrogen contributed most to the residual total nitrogen in effluent. In contrast, phenol could not decrease total nitrogen in effluent effectively to less than $35 \mathrm{mg} / \mathrm{L}$ in its tested phenol dosage range (370-1200 mg/L) due to less efficiency in denitrification and therefore resulted in higher $\mathrm{NO}_{2,3}{ }^{-}{ }^{-} \mathrm{N}$ residue in effluent. In conclusion the results strongly suggested that the modified $\mathrm{A} / \mathrm{O} / \mathrm{A} / \mathrm{O}$ process with sodium acetate or methanol as external carbon source could successfully achieve the goal for total nitrogen removal based on the issued Shanghai Discharge Standard (DB31/1992009).
\end{abstract}

Keywords: Coking wastewater treatment, A/O/A/O process, Total nitrogen removal, Denitrification, External carbon source.

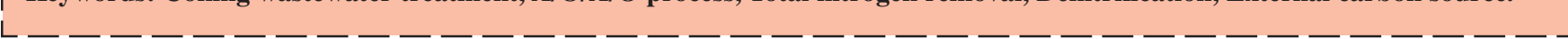

\section{INTRODUCTION}

Coking wastewater, commonly generated from coal carbonization and fuel classification processes in iron and steel industry, is one of the most toxic industrial effluent. It usually contains various refractory organic compounds including polyaromatic hydrocarbons and heterocyclic nitrogenous compounds, as well as certain toxic compounds such as phenols, thiocyanates, cyanides, sulphides and chlorides ${ }^{1,2}$. Another characteristic of coking wastewater is that it also contains highstrength ammonium and organic nitrogens which are generally in a level of several hundreds of $\mathrm{mg} / \mathrm{L}$ even after pre-treatment through ammonia stripping process ${ }^{3}$. Currently biological treatment, such as anoxic-oxic $(\mathrm{A} / \mathrm{O})^{4}$ or anaerobic-anoxicoxic $(\mathrm{A} / \mathrm{A} / \mathrm{O})^{5,6}$ process, is widely applied for coking wastewater treatment due to its mature technology and cost-effective aspects, in which heterotrophic microorganisms are responsible for organic degradation and conversion of organic nitrogen to ammonium nitrogen, while autotrophic ones for conversion of ammonia to nitrate or nitrite. In addition, through the recycling of nitrified water to the non-oxygen zone denitrification could be fulfilled ${ }^{7-9}$. However, it is well known that during denitrification a certain amount of carbon is required for denitrifier and it is commonly recognized that the ratio of chemical oxygen demand (COD) to total nitrogen (TN) should be over 7.0 and the lower ratio would result in poor denitrification due to the scarcity of available carbon for microorganisms utilization ${ }^{10}$.

The coking wastewater from Shanghai Baosteel Chemical Co. Ltd. contains higher COD and nitrogen, in which both ammonium nitrogen and organic nitrogen are in significant levels. The wastewater treatment plant (WWTP) was designed initially for COD and $\mathrm{NH}_{4}{ }^{+}-\mathrm{N}$ removals where anoxic-oxic (A/O) process was applied. However, in 2009 a new Shanghai Discharge Standard (DB31/199-2009) was issued in which effluent parameters including COD $\leq 100 \mathrm{mg} / \mathrm{L}, \mathrm{NH}_{4}{ }^{+} \mathrm{N} \leq 15$ $\mathrm{mg} / \mathrm{L}$ and total nitrogen $\leq 35 \mathrm{mg} / \mathrm{L}$ were required. Even the former treatment plant could reach the discharge standards in COD and $\mathrm{NH}_{4}{ }^{+}-\mathrm{N}$ parameters, in contrast, total nitrogen in effluent was always in a range of $96-242 \mathrm{mg} / \mathrm{L}$ with a mean value of $158 \mathrm{mg} / \mathrm{L}$. Therefore denitrification unit should be necessary in reform of the plant in order to lower effluent total nitrogen to less than $35 \mathrm{mg} / \mathrm{L}$. 
Hence, the aim of this study is to enhance the effluent total nitrogen removal by modifying the existed WWTP by the addition of an anoxic zone in its current aerobic reactors to form $\mathrm{A} / \mathrm{O} / \mathrm{A} / \mathrm{O}$ process. On the other hand, some readily degradable organic compounds are selected as the external carbon in anoxic zone for denitrification occurrence and the whole performance was evaluated.

\section{EXPERIMENTAL}

All chemicals used were of analytical-reagent grade. The analyses including $\mathrm{COD}, \mathrm{NH}_{4}{ }^{+}-\mathrm{N} \mathrm{NO}_{2}{ }^{-}-\mathrm{N}, \mathrm{NO}_{3}^{-}-\mathrm{N}$, total nitrogen, mixed liquid suspended solid (MLSS) and mixed liquid volatile suspended solid (MLVSS) were based on the Standard Methods for the Examination of Water and Wastewater ${ }^{11}$ and organic nitrogen was calculated according to nitrogen mass balance. The $\mathrm{pH}$ was recorded using a $\mathrm{pH}$ meter (PHB-2, Shanghai Sanxin Instrumental Company, Shanghai, China) and the dissolved oxygen (DO) using a DO meter (JPB607, Shanghai Stech Company, Shanghai, China).

Flow chart of wastewater treatment process: The WWTP was operated in A/O process and its total treatment capacity for phases 1 and 2 in Shanghai Baosteel Chemical Co. Ltd. was designed at $208 \mathrm{~m}^{3} / \mathrm{h}$. In order to simulate the full plant performance a lab-scale treatment facility was established and all operational parameters were the same as the full plant except the treatment capacity being lowered to $2.0 \mathrm{~L} / \mathrm{h}$ (Fig. 1). The lab-scale test was run as A/O process and composed of three reactors and two sedimentation tanks with the valid working volumes of 45, 105.6, 51.9, 11.6 and $20.0 \mathrm{~L}$ and hydraulic retention times of 22.5, 52.8, 26, 5.8 and $2.0 \mathrm{~h}$ for reactors 1, 2, 3 and sedimentation tanks 1 and 2, respectively. Reactor 1 was packed with semi-soft media that was constructed of plastic rings and synthetic fiber string for biofilm growth. One third of reactor 2, i.e., R2-1, was stirred by a submersible pump and the left (R2-2) was aerated by air pump. The DO concentration was maintained at a range of 2.0-5.4 $\mathrm{mg} / \mathrm{L}$ in aerobic compartment and MLSS in Reactors 2 and 3 in a range of 2000-3000 mg/L with the ratio of MLVSS/MLSS of 0.86 . During the whole test period temperature was kept at $30 \pm 2{ }^{\circ} \mathrm{C}$.

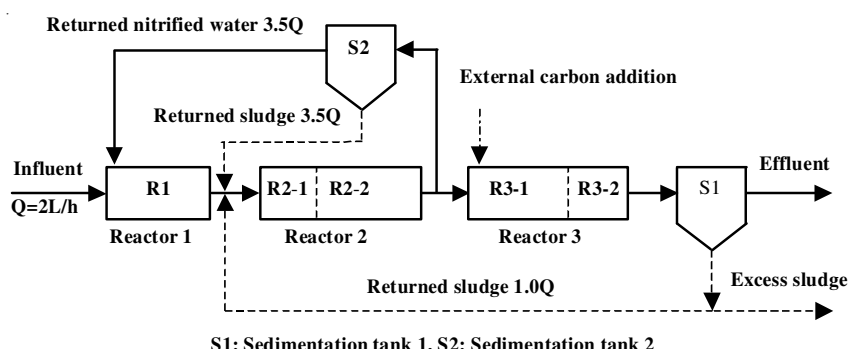

Fig. 1. Schematic diagram of lab-scale experimental setup

Characteristics of coking wastewater: The COD and nitrogen concentrations in raw coking wastewater are shown in Table-1. It can be seen that $\mathrm{NH}_{4}{ }^{+}-\mathrm{N}$ and organic nitrogen composed most of total nitrogen and nitrate or nitrite are negligible. The ratio of COD to total nitrogen was around 4.95, much less than 7.0. Therefore external carbon should be added for denitrification purpose.
TABLE-1

CHARACTERISTICS OF RAW COKING WASTEWATER

\begin{tabular}{cc}
\hline Item & Concentration range $(\mathrm{mg} / \mathrm{L})$ \\
\hline $\mathrm{COD}$ & $690-1470(1025)^{*}$ \\
Total nitrogen & $125-296(209)$ \\
$\mathrm{NH}_{4}^{+}-\mathrm{N}$ & $60-212(134)$ \\
$\mathrm{Organic}^{+} \mathrm{N}$ & $38-128(76)$ \\
$\mathrm{NO}_{2}^{-}-\mathrm{N}$ & $0.5-1.9(1.2)$ \\
$\mathrm{NO}_{3}^{-}-\mathrm{N}$ & $0.02-0.4(0.2)$ \\
$\mathrm{pH}$ & $8.1-8.3(8.2)$ \\
\hline "Data in parenthesis are mean values. &
\end{tabular}

Modification of $\mathbf{A} / \mathbf{O}$ treatment process: The process was modified by allocating an anoxic zone ( $2 / 3$ volume) from reactor 3 in order to create an anoxic environment for denitrification occurrence, i.e., the former $\mathrm{A} / \mathrm{O}$ process was therefore changed to anoxic-oxic-anoxic-oxic (A/O/A/O) process. The external carbons such as sodium acetate, methanol and phenol were added in this anoxic zone, respectively. In each operational condition the running time lasted at least 2 weeks and the samples at the steady state conditions were collected. The measurements of the parameters were conducted in duplicate and the mean values reported. The relative errors of these measurements were less than $5 \%$.

\section{RESULTS AND DISCUSSION}

Performance of lab-scale test in simulation of on-site A/O process: The simulated lab-scale performances are shown in Table-2. After A/O process treatment $\mathrm{COD}, \mathrm{NH}_{4}{ }^{+}-\mathrm{N}$ and total nitrogen removals achieved $68.8,98.3$ and $27.5 \%$ with the mean values of $312,3.1$ and $158 \mathrm{mg} / \mathrm{L}$ in effluent, respectively. Apparently applying the current $\mathrm{A} / \mathrm{O}$ process only $\mathrm{NH}_{4}{ }^{+}-$ $\mathrm{N}$ concentration in effluent could satisfy the discharge requirement, whereas COD could also be easily lowered to the discharge standard by the followed coagulation unit with the addition of mixed inorganic and organic coagulants ${ }^{12,13}$. However, the total nitrogen in effluent was significantly higher than the discharge standard and further analyses showed that $\mathrm{NO}_{3}{ }^{-}$ - $\mathrm{N}$ and organic nitrogen contributed 91 and $7.0 \%$ of total nitrogen, respectively. Therefore it can be concluded that lower denitrification efficiency was responsible to the higher $\mathrm{NO}_{2,3}{ }^{-}$ - $\mathrm{N}$ in effluent and enhancing the denitrification by modifying the $\mathrm{A} / \mathrm{O}$ process into $\mathrm{A} / \mathrm{O} / \mathrm{A} / \mathrm{O}$ along with the external carbon addition was tested in the followed study and sodium acetate, methanol and phenol were selected and tested individually.

TABLE-2

PERFORMANCE OF SIMULATED LAB-SCALE A/O PROCESS

\begin{tabular}{cccc} 
Item & Influent $(\mathrm{mg} / \mathrm{L})$ & Effluent $(\mathrm{mg} / \mathrm{L})$ & Removal $(\%)$ \\
\hline $\mathrm{COD}$ & $580-1480(1000)^{*}$ & $216-384(312)$ & $46.6-85.0(68.8)$ \\
$\mathrm{NH}_{4}{ }^{-} \mathrm{N}$ & $97-307(182)$ & $0.5-6.2(3.1)$ & $96.7-99.8(98.3)$ \\
$\mathrm{TN}$ & $122-332(218)$ & $96-242(158)$ & $17.0-59.7(27.5)$ \\
\hline *Data in parenthesis are mean values; TN = Total nitrogen.
\end{tabular}

Performance of modified A/O/A/O process with sodium acetate as external carbon source: Four levels of sodium acetate concentrations, namely 625, 1250, 1875 and $2500 \mathrm{mg} / \mathrm{L}$, were added in the front part of R3-1 reactor as external carbon source for microorganism utilization aiming for denitrification. At the steady state condition samples were taken and analyzed and the results are shown in Fig. 2. With the increase of sodium 


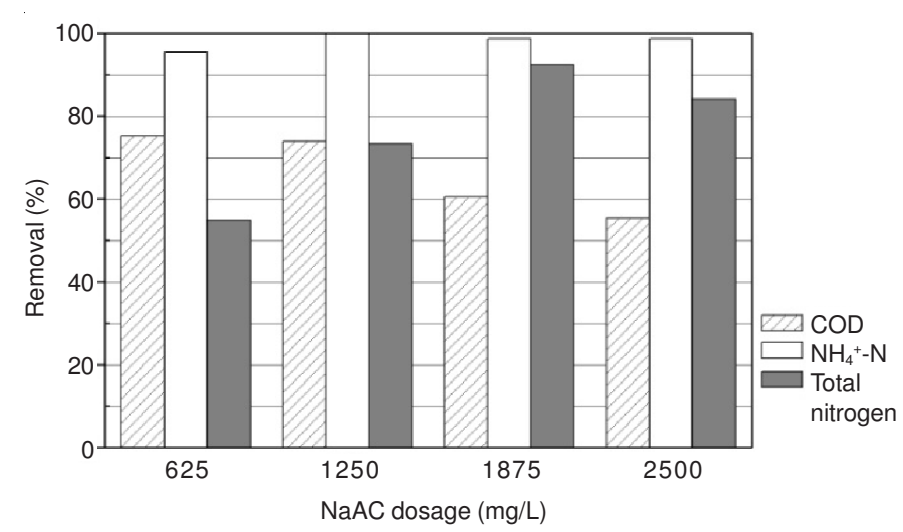

Fig. 2. $\mathrm{COD}, \mathrm{NH}_{4}{ }^{+}-\mathrm{N}$ and total nitrogen removals with sodium acetate as external carbon

acetate dosage COD removals slightly decreased as 75.2, 73.9, 60.5 and $55.4 \%$, whereas COD concentrations in effluent increased from 214 to 253,340 and $387 \mathrm{mg} / \mathrm{L}$, respectively. This increase corresponding to COD removal decrease was simply due to the increase of sodium acetate dosage. At the same time, $\mathrm{NH}_{4}{ }^{+}-\mathrm{N}$ removals were always higher than $96 \%$ and $\mathrm{NH}_{4}{ }^{+}-\mathrm{N}$ concentrations in effluent were lower than $5 \mathrm{mg} / \mathrm{L}$. However, total nitrogen removals increased significantly with the increase of sodium acetate dosage, from 54.9-73.3, 92.4 and $84.1 \%$ corresponding to total nitrogen concentrations in effluent of 82, 56, 14.5 and $29 \mathrm{mg} / \mathrm{L}$, respectively. It should be noted that the lowest total nitrogen concentration in effluent was achieved with the sodium acetate dosage of $1875 \mathrm{mg} / \mathrm{L}$ and total nitrogen was consisted of most organic nitrogen (85\%), ammonium nitrogen $(14 \%)$ and $\mathrm{NO}_{2,3}{ }^{-} \mathrm{N}$ was completely negligible. Apparently, lower sodium acetate dosage could not achieve complete denitrification resulting in inefficient $\mathrm{NO}_{3}^{-}$$\mathrm{N}$ and $\mathrm{NO}_{2}^{-}-\mathrm{N}$ removal. Whereas, the increase of total nitrogen concentration in effluent with sodium acetate dosage to 2500 $\mathrm{mg} / \mathrm{L}$ was probably due to $\mathrm{pH}$ increase $(\mathrm{pH}=8.56)$ in anoxic zone and therefore inhibited denitrification proceeding. From above results it can be concluded that with the modified $\mathrm{A} / \mathrm{O} /$ $\mathrm{A} / \mathrm{O}$ process and sodium acetate dosage of $1875 \mathrm{mg} / \mathrm{L}$ as external carbon the denitrification process was significantly enhanced and the effluent could well satisfy total nitrogen discharge standard.

Performance of modified A/O/A/O process with methanol as external carbon source: Three levels of methanol concentrations, namely 440, 700 and $880 \mathrm{mg} / \mathrm{L}$, were added in the front part of R3-1 reactor as external carbon source. At the steady state condition samples were taken and analyzed and the results are shown in Fig. 3. With the increase of methanol dosage COD removals slightly decreased as 71, 71.9 and $65.4 \%$, whereas COD concentrations in effluent were in a range from 290 to $340 \mathrm{mg} / \mathrm{L}$. $\mathrm{NH}_{4}{ }^{+}-\mathrm{N}$ removals were always higher than $98.5 \%$ and $\mathrm{NH}_{4}{ }^{+}-\mathrm{N}$ concentrations in effluent were lower than $1.6 \mathrm{mg} / \mathrm{L}$. However, total nitrogen removals increased significantly with the increase of methanol dosage, from 74.1 to 77.3 and $89.5 \%$ corresponding to total nitrogen concentrations in effluent of $51.7,47.7$ and $17.6 \mathrm{mg} / \mathrm{L}$. The lowest total nitrogen concentration in effluent was achieved with the methanol dosage of $880 \mathrm{mg} / \mathrm{L}$ and total nitrogen was consisted of most organic nitrogen $(88 \%), \mathrm{NO}_{3}^{-}-\mathrm{N}(6 \%)$,

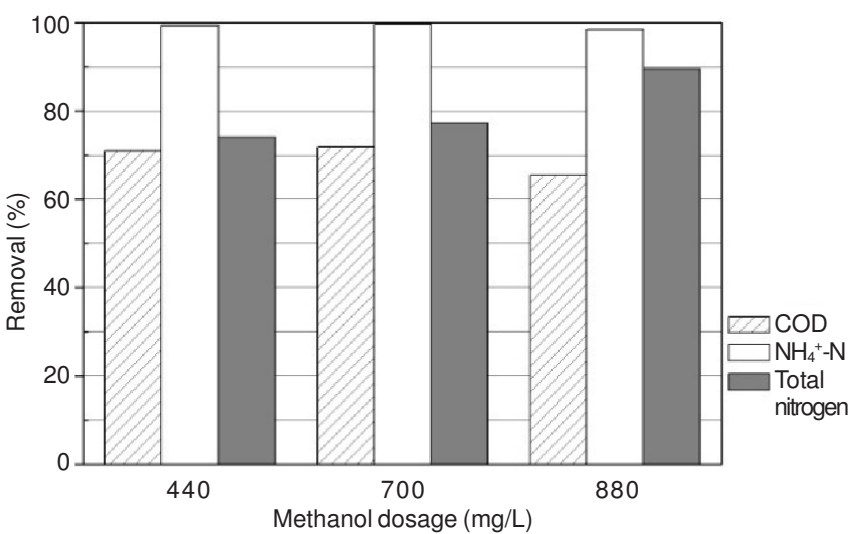

Fig. 3. $\mathrm{COD}, \mathrm{NH}_{4}{ }^{+}-\mathrm{N}$ and total nitrogen removals with methanol as external carbon

ammonium nitrogen $(4 \%)$ and $\mathrm{NO}_{2}^{-}-\mathrm{N}(2 \%)$. Lower methanol dosage could not achieve complete denitrification resulting in inefficient $\mathrm{NO}_{3}{ }^{-}-\mathrm{N}$ and $\mathrm{NO}_{2}^{-}-\mathrm{N}$ removal. From above results it can be concluded that with the modified $\mathrm{A} / \mathrm{O} / \mathrm{A} / \mathrm{O}$ process and methanol dosage of $880 \mathrm{mg} / \mathrm{L}$ as external carbon the denitrification process was significantly enhanced and the effluent could well satisfy total nitrogen discharge standard.

Performance of modified A/O/A/O process with phenol as external carbon source: As the phenol is a by-product in Shanghai Baosteel Company, using the phenol as an external carbon source was tested in this study and compared with other two carbon sources. Four levels of phenol concentrations, namely 370, 620, 830 and $1200 \mathrm{mg} / \mathrm{L}$, were added in the front part of R3-1 reactor as external carbon source. At the steady state condition samples were taken and analyzed and the results are shown in Fig. 4. With the increase of phenol dosage COD removals of $72.6,80.8,68.4$ and $75.3 \%$ were obtained, respectively, whereas COD concentrations in effluent were in a range from 250 to $290 \mathrm{mg} / \mathrm{L}$. $\mathrm{NH}_{4}{ }^{+}-\mathrm{N}$ removals were always higher than $99.6 \%$ and $\mathrm{NH}_{4}{ }^{+}-\mathrm{N}$ concentrations in effluent were lower than $0.6 \mathrm{mg} / \mathrm{L}$. In addition, total nitrogen removals of 78.1, 83.6, 79.3 and 75.2\% were also achieved, respectively, corresponding to total nitrogen concentrations in effluent of 43.3, 35.9, 44.1 and $60.0 \mathrm{mg} / \mathrm{L}$. The lowest COD and total nitrogen concentrations in effluent achieved with the phenol dosage of $620 \mathrm{mg} / \mathrm{L}$, but still higher than the required value of discharge standard. The further analyses showed that the total nitrogen in effluent was consisted of most $\mathrm{NO}_{2,3}{ }^{-} \mathrm{N}(66 \%)$ and organic nitrogen (33\%) and ammonium nitrogen was negligible. Apparently denitrification was not complete. In addition, microorganisms grew quickly when degrading phenol, therefore resulting in higher MLSS in the reactor and poor sludge sedimentation. From the above results it can be concluded that with the modified $\mathrm{A} / \mathrm{O} / \mathrm{A} / \mathrm{O}$ process phenol was not suitable as external carbon for denitrification purpose in this study.

\section{Conclusion}

The former A/O process operated in Shanghai Baosteel Chemical Co. Ltd. for coking wastewater treatment was modified to A/O/A/O process and a lab-scale test were performed. The results indicated that both sodium acetate and methanol were suitable as external carbon source for denitrification 


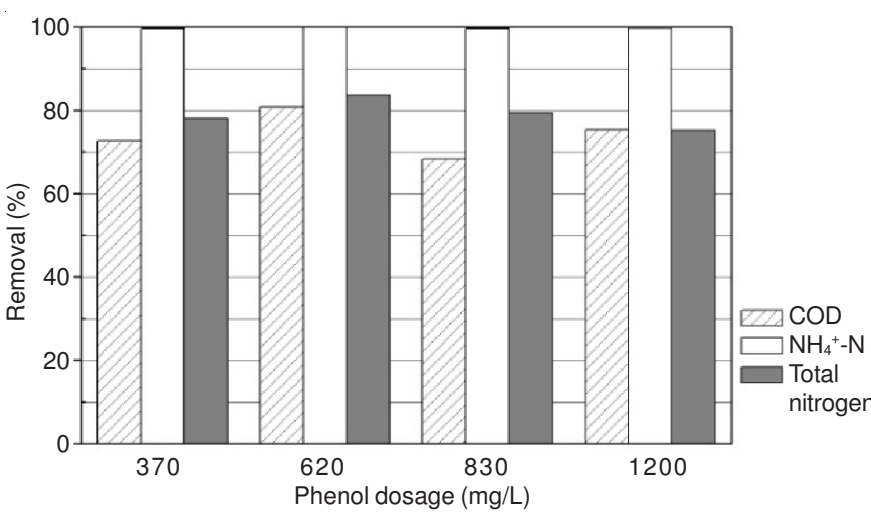

Fig. 4. $\mathrm{COD}, \mathrm{NH}_{4}{ }^{+}-\mathrm{N}$ and total nitrogen removals with phenol as external carbon

purpose, while phenol, a by-product of Shanghai Baosteel Company, was not. The above results strongly suggested that the modified $\mathrm{A} / \mathrm{O} / \mathrm{A} / \mathrm{O}$ process with sodium acetate or methanol as external carbon source could achieve the goal for total nitrogen removal based on the issued Shanghai Discharge Standard (DB31/199-2009).

\section{ACKNOWLEDGEMENTS}

This study was financially supported by the Grant from the National Natural Science Foundation of China (No. 41373094), Shanghai Natural Science Funds (No. 12ZR1408000) and the Fundamental Research Funds for the Central Universities.

\section{REFERENCES}

1. Y.M. Kim, D.H. Park, C.O. Jeon, D.S. Lee and J.M. Park, Bioresour. Technol., 99, 8824 (2008).

2. H.Q. Li, H.J. Han, M.A. Du and W. Wang, Bioresour. Technol., 102, 4667 (2011).

3. M. Minhalma and M.N. de Pinho, J. Membr. Sci., 242, 87 (2004).

4. P. Lai, H.Z. Zhao, Z.F. Ye and J.R. Ni, Process Biochem., 43, 229 (2008).

5. W.T. Zhao, X. Huang and D.J. Lee, Sep. Purif. Technol., 66, 279 (2009).

6. W.T. Zhao, X. Huang, D.J. Lee, X.H. Wang and Y.X. Shen, J. Membr. Sci., 330, 57 (2009).

7. Y.E. Ba and Z. Li, Adv. Mater. Res., 383, 3729 (2012).

8. H. Li, H. Cao, Y. Li, Y. Zhang and H. Liu, Environ. Eng. Sci., 27, 313 (2010).

9. E. Maranon, I. Vazquez, J. Rodriguez, L. Castrillon, Y. Fernandez and H. Lopez, Bioresour. Technol., 99, 4192 (2008).

10. Y.M. Li, G.W. Gu, J.F. Zhao, H.Q. Yu, Y.L. Qiu and Y.Z. Peng, Chemosphere, 52, 997 (2003).

11. APHA, American Public Health Association, Washington, DC, edn 18 (1992).

12. Z. Wang, G. Le, Y. Shi and G. Wegrzyn, Process Biochem., 38, 777 (2002).

13. Y. Wang, Y. Lv, M. Shan and D. Pan, Appl. Mech. Mater, 108, 257 (2012). 